\title{
MICROTHAMBEMA TENUIS N. GEN., N. SP. (ISOPODA ASELLOTA) AND RELATIONS OF SOME ASELLOTE ISOPODS
}

\author{
BY
}

\author{
I. A. BIRSTEIN \\ Biological Faculty of the Moscow State University
}

During the expeditions of the Soviet research vessel "Vitjaz" in the Northwestern Pacific many deep-sea Isopods mainly belonging to the suborder Asellota were collected. Among them one species presents a great interest. This species must be assigned to a new genus closely related to the genera Thambema Stebbing, Microparasellws Karaman, Microcharon Karaman, Angeliera Chappuis and Delamare (= Brevipleonida Gnanamuthu), Microjaera Bocquet and Lévi, Mackinia Matsumoto, Caectaniropsis Menzies and Petit, Protocharon Chappuis and Delamare and probably too to the genus Ectias Richardson.

\section{Microthambema new genus}

Def i n i t isn. Body extlemely slendet. Head with round prominent frontal area. Eyes absent. First antenna short, with 6 segments. Second antenna longer than head, multiarticulated, squitma lacking. Mandibles normal, molar process well developed and truncated at apex, lacinia present on left mandible, palp 3segmented. Maxilliped with 2 coupling hooks. Maxillipedal palp 5-segmented, the first three segments expanded, wider than endite. All peraeon somites free. Peraeon somite 1 shorter than all others, peraeon somites 4-7 elongated. Peraeopod 1 prehensile, the last six peraeopods of moderate length, their dactyli with one claw, Carpus of peraeopods 2.4 expanded. Pleon consists of two movable somites. Pleotelson elongated, oval, with rounded posterior margin. Pleopods 1 and 2 normal, pleopods 3 and 4 uniramous. Uropods biramous, with peduncle, exo. podite short.

Type species: $M$. tenuis n. sp.

Mictothambema tenuis new species (figs. 1, 2)

Materjal: One male. $2.7 \mathrm{~mm}$ long and $0.32 \mathrm{~mm}$ wide at fitst peraeonal somitc: "Vitjaz", station No, $3886,31^{\circ} 11.0^{\prime}$ N. $143^{\circ} 09.7^{\prime}$ E.. depth $5680.5690 \mathrm{~m}$.

Description: Body elongated, 8.5 times longer than broad (width of peraeon somite 1 ).

Head longer than broad, protruding between the antennae into a semicircular lobe. Eyes lacking. 
Peraeon somites 1-3 increase in length but decrease in width from 1 to 3 . Anterior margin of these somites broader than the posterior. Peraeon somites 4-7 equally long, each somite $13 / 4$ as long as somite 1 , anterior margin narrower than posterior.

Pleon consists of two movable somites, the first narrower and only $1 / 6$ as long as the second. The second somite oval, $13 / 4$ as long as broad, with semicircular posterior margin, longer than each of the posterior peraeon somites.

First antenna (fig. 2a) shorter than head, consists of six segments. The second
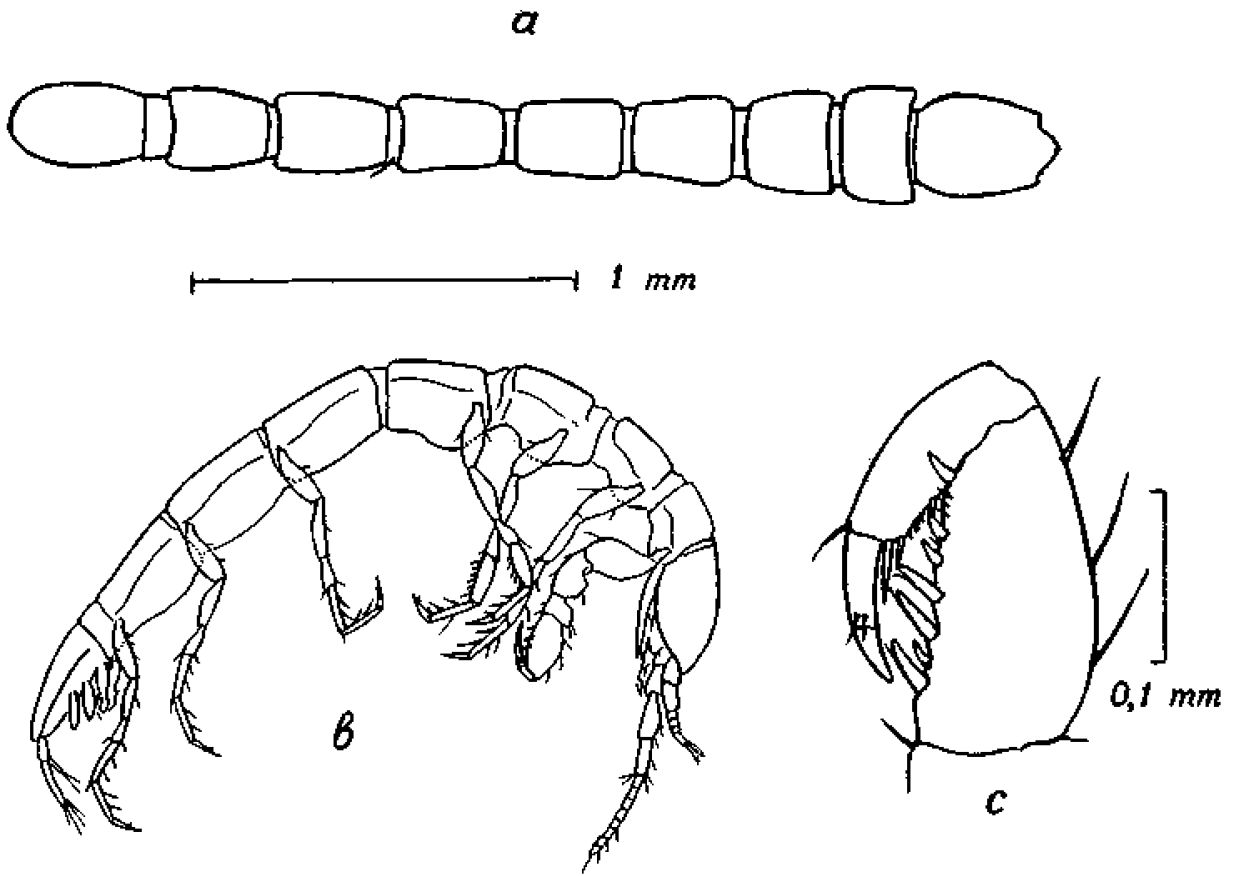

Fig. 1. Microthambema tenuis n. gen,, n. sp. a, in dorsal view; b, in lateral view; c, terminal part of perteopod 1.

segment is $11 / 2$ times longer than the first. Second and last segments furnished with one large sensory filament.

Second antenna (fig. 2b) twice as long as the first antenna. The first three segments of peduncle short, the fourth slightly shorter than the fifth; the fifth and sixth segments subequal in length, but the last somewhat broader. The 8segmented flagellum about as long as the last two segments of the peduncle together.

Right mandible (fig. 2c) has a cutting edge with five blunt teeth. Five spines in the spine-row. Molar process strong, sub-cylindrical, the three-segmented palp well developed, with strongly curved terminal segment. Left mandible with cutting edge like that of the right mandible, spine-row consists of three spines only, the movable lacinia short. with four teeth. 


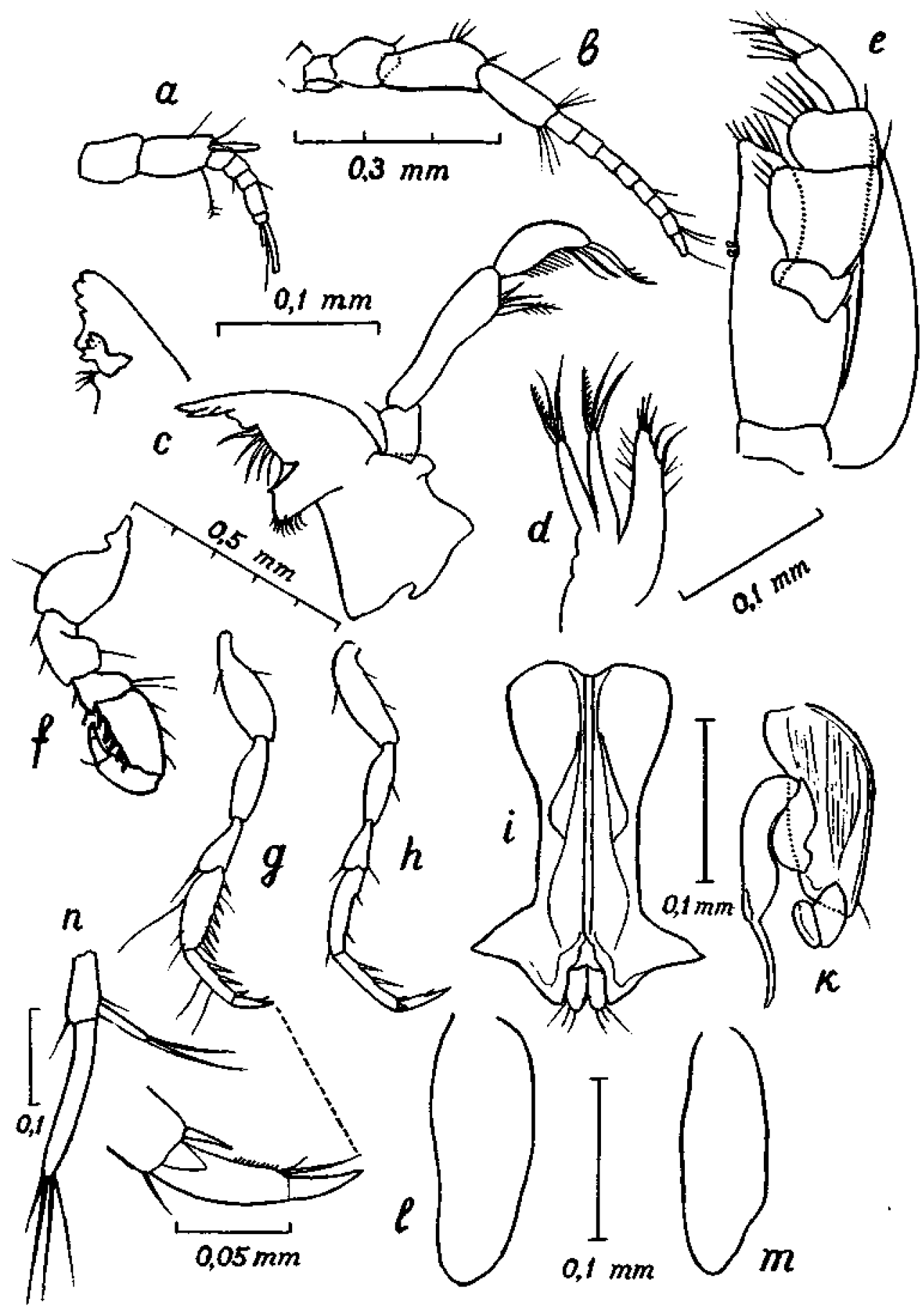

Fig. 2. Microtbambema tenais n. gen., n. sp. a, first antenna; b, second antenna; c, right and left mandible; d, second maxilla; e, maxilliped; f, first peraeopod; g, second peraeopod; h, seventh peraeopod; $i$, first pleopod; $k$, second pleopod; l, third pleopod; m, fourth pleopod; $n$, uropod. 
Maxilla 1 and 2 (fig. 2d) typically shaped, as in Thambema amicorum Stebbing. Maxilliped (fig. 2e) like that in $T \vec{b}$. amicoram, with two coupling hooks, but the epipodite longer than in $T h$. amicorum, reaching the distal margin of the endognath. Palp 5-segmented, in its broadest part $11 / 2$ times wider than the endite.

Peraeopod 1 (figs. 1c, 2f) stouter but shorter than other peraeopods. Basis, ischium and merus much expanded distally. Carpus narrows distally, twice as long as its greatest width, with seven stout unequal spines on the lower margin. Propodus slightly curved, shorter than carpus, dactylus $11 / 2$ times shorter than the carpus.

Peraeopods 2 (fig. $2 \mathrm{~g}$ ), 3 and 4 subequal in shape and size. Basis longer than each of the succeeding segments, expanded at the middle. Ischium and merus almost equally long, ischium with six to seven spines, merus with two spines along the anterior convex margin. Propodus shorter than merus and ischium.

Peraeopods 5, 6 and 7 (fig. 2h) almost as long as the preceding peraeopods but basis more elongated and carpus more slender. No spines along the anterior margin of carpus. All dactyli provided with one claw.

Pleopod 1 (fig. 2i) in general form similar to that of an anchor. The base rounded, the outer distal corners ptotruding outwards in triangular lobes. The endopodites slightly projecting and furnished each with three hairs.

Pleopod 2 (fig. $2 \mathrm{k}$ ) like in Thambema amicorum but endopodite considerably longer. Exopodite two-segmented. Sympodite with one hair at the inner distal corner.

Pleopods 3 and 4 (figs. 2l, 2m) uniramous, oval.

Uropod terminal, shorter than pleotelson. Exopodite almost as long as peduncle, endopodite three times longer and broader than exopodite.

\section{SYSTEMATIC POSITION}

Though Microtbambema tenuis n. sp. has many features in common with Thambema amicorum Stebbing, a complete comparison of these species presents some difficulties because the description given by Stebbing (1913) is not quite correct, as has been already pointed out by Bocquet and Lévi (1955) and Menzies and Petit (1956).

Thus the utopods of $T h$. amicorum are probably broken off, not lacking, as thought Stebbing (Bocquet and Lévi, 1955), and the pleon consists of two somites rather than of one, as described by Stebbing (Menzies and Petit, 1956); indeed a slight indication of a first free somite can be discerned on the figure given by Stebbing himself (plate 26). Furthermore the maxillipedal palp of Th. amicorum is not four-segmented, but five-segmented. Here too our statement is confirmed by the figure of Stebbing, showing the beginning of a suture between the first and the second segments. If these corrections are accepted the close rela- 
tion of Microtbambema tenuis and Tbambema amicormm becomes quite evident.

The two genera are similar in respect to the form of body, head and pleotelson; the structure of all appendages is very similar too, with the exception of pleopods 1,3 and 4 (the structure of the uropods of $T b$. amicormm is as yec unknown). The difference between the pleopods 1 is a minor one: in $T h$. amicortum the exopodites of the pleopod 1 are less expanded distally and the endopodites are much longer and protrude farther out of the incisure of the distal margin of the exopodites as compared with $M$, tenuis. The difference in structure of pleopods 3 and 4 is essential: they are biramous in $T b$. amicorum and uniramous in $M$. tenuis. Due to these differences the species considered must be referred to different though closely related genera.

They are nearer to one another than either of them to any other genus. From all the genera listed above, which resemble Thambema and Microtbambema by their slender body and well developed first abdominal somite $T h$. amicorum and $M$, tenuis differ by a strong prehensile first peraeopod and the presence of one claw on the dactyli of the other peraeopods, as well as by a longer epipodite of the maxilliped, extending beyond the second segment of the palp.

The position of these two genera as well as of the related genera Micropart. sellus, Microcharon, Angeliera, Microjaera, Mackinia, Caecianiropsis, Protocbaron in the system of the suborder Asellota still remains obscure.

Bocquet and Lévi (1955), who did not recognise the Microparasellidae Karaman as a self-contained family, suggested that the genera Microparasellus, Microcharon, Angeliera and Brevipleonida referred to this family should be assigned, together with the new genus Microjaera and, possibly, the genera Tbambema and Ectias to a new subfamily Microjanirinae, which, in their opinion, belongs to the family Janiridae. They regard the tendency to a reduction of respiratory pleopods as an essential distinguishing character of the Microjanitinae.

Chappuis (1959) in his critical analysis points out a basic difference between the Microparasellidae and the Janiridae, namely the structure of the mandibular molar process, cone-shaped in the Microparasellidae and subcylindrical in the Janiridae. As to the tendency to a reduction of respiratory pleopods Chappuis associates this feature with the small size of the animals that makes integumentary respiration possible. This statement of Chappuis is confirmed by the material studied by us: the respiratory pleopods of the small Microihambema tenuis are fat more reduced than those of the latger Tbambema amicorum.

According to Chappuis the genera Microparasellus, Microcharon and Angeliera (= Brevipleonida) belong to the family Microparasellidae, whereas the genera Caecianiropsis and Microjaerd must be assigned to the family Janiridae; the systematic position of the genera Mackinia and Protocbaron remains unknown, the genus Ectias has to be considered incertae sedis. No mention is made by this author of the genus Tbambema.

Not all of these statements seem convincing. Thus the genera Microjaera and Caecianiropsis, though possessing well-developed mandibular molar processes can- 
not be included into the family Janiridae because of their relatively large free first abdominal somite, never encountered in genera of the family Janiridae but inherent to the family Microparasellidae. This primitive character connects the genera Microjaera, Caecianiropsis, Tbambema, Microthambema, all the Microparasellidae and Protocharon.

In regard to Mackinia, Matsumoto (1956) who has described this genus, does not indicate in his text the number of pleonal somites, though in his drawing two free somites are represented before the pleotelson. The attribution of Mackinia to the Paraselloidea is obvious and is accepted by Matsumoto too, but as no representatives of this superfamily are known to possess a three-segmented abdomen, which is chatacteristic of the superfamily Aselloidea, it must be surmised that an error has been committed in the figure given by Matsumoto and that in reality Mackinia, like all other genera mentioned above, has but one free abdominal somite before the pleotelson.

A second character which prevents the inclusion of Caecianiropsis, as well as of Prolocbaron, Mackinia and all the Microparasellidae into the family Janiridae is the structure of the first pair of peraeopods which in all these genera is like or nearly like that of all other peraeopods. In this respect Microjaera is near to the 'Thambematidae and most Janiridae, though among the latter repre. sentatives are known with an undifferentiated peraeopod 1 (as for instance faer $\mathrm{d}$ ).

Such features as body form, the presence of a well developed first free abdominal somite and the number of claws on the dactyli of peraeopods 2.7 must be regarded as more important distinguishing characters than the form of the mandibular molar process, the more so that even among the typical Janiridae one finds representatives with a cone-shaped rather than a cylindrical molar ptocess, as for instance in the genus Katianira Hansen.

Consequently the genera considered here, characterised by the presence of a first free abdominal somite and a slender elongated body, may be grouped into three families:

I. Thambematidae Stebbing. Peraeopod 1 prehensile, differing sharply from the others. Dactyli of peraeopods 2 to 7 with one claw. Mandibular molar process subcylindrical. Thambema Stebbing and Microlbambema n. gen.

2. Microparasellidae Kataman. Peraeopod 1 not prehensile, similar in structute to all the others. Dactyli of peraeopods 2 to 7 with 2 to 3 claws. Mandibular molar process conical or reduced. Pleopod 1 of the male broader at the base than distally. Microparasellus Kataman, Microcharon Karaman and Angeliera Chappuis and Delamare.

3. Microjaniridae Bocquet and Lévi (new combination). Peraeopod 1 slightly differentiated or not differentiated. Dactyli of peraeopods 2 to 7 with 2 claws. Mandibular molar process subcylindrical. Pleopod 1 of the male narrower at the base than distally (with the exception of Mackinia). Microjaera Bocquet and Lévi, Caecianiropsis Menzies and Petit, Protocbaron Chappuis and Delamare and Mackinia Matsumoto. 
All three families are closely connected with the family Janiridae, though each of them by different characters. The family Thambematidae is similar to the Janiridae by their prehensile peraeopod 1 but differs by the dactyli of all other peraeopods. Contrariwise the Microjaniridae and the Microparasellidae, resembling the Janiridae in respect to the structure of dactyli of peraeopods 2 to 7 , differ by their peraeopod 1 being not prehensile. However, the Micropatasellidae differ from most Janiridae by the structure of mandibulat molar process.

According to Menzies (1956) the new family Echinothambemidae, which he has described from the Puerto-Rico trench, is near to the Thambematidae. It seems to me, however, that these families are distant from one another, since in the Echinothambemidae the posterior thoracic somites are fused together and with both the abdominal somites; they have no mandibular palp and are characterised by a peculiar structure of the first antenna, single-segmented uropods, etc. The Thambematidae oy ineir characteristic features are nearer to the Janitidae, Microparasellidae and Microjaniridae than to the Echinothambemidae.

The well-developed free first abdominal somite, inherent to the Thambernatidae, Microparasellidae and Mictojaniridae, distinguishing them from the Janiridae, can be considered a primitive character, indicative of a close relation between these three families. It is highly probable that they have retained this feature, associated with acute bending of the body, owing to their mode of life in capillaries between soil particles. We are as yet entirely ignorant of the mode of life of the abyssal Thambematidae, but it may be inferred from their body form similar to that of the Microparasellidae and Microjaniridae, that they too live in capillaries between soil particles.

\section{DISTRIBUTION}

The families Microparasellidae and Microjanitidae in the sense suggested in this paper have a similat distribution. Representatives of both families are known from interstitial fresh and marine shallow waters.

Among the three genera of the family Microparasellidae the genus Microparasellus with its two species occurs solely in fresh subterranean waters of Jugosiavia and North Africa. The genus Microcbaron (identical with the genus Duslenia Lévi - see Birstein, 1952 and Chappuis and Delamare, 1954) included 10 species from fresh interstitial waters of Jugoslavia, Rumania, Hungary and Corsica and 3 marine shallow water psammophile species found in the English Channel off . Plymouth and on the Mediterranean coasts of Italy and France (Chappuis and Delamare, 1954; Spooner, 1959; Karaman, 1959). And finally the genus Angeliera, with two species, occurs in ftesh, brackish and marine interstitial waters of South France and Italy and in marine interstitial waters of India (Schulz, 1954; Gnanamuthu, 1954).

The family Microjaniridae indudes four genera. Among them, the monotypic genera Microjaera and Caecianiropsis are recorded from marine shallow waters 
of France and California, the monotypic genus Mackinia and the genus Protocharon, with two species, inhabit fresh interstitial waters of Japan, of Réunion Island and of Amsterdam Island.

A characteristic feature of both families under consideration, besides their being confined to marine and fresh interstitial waters, is the discontinuity of the ranges of distribution of certain genera. Thus for instance the genus Angeliera is known from France, Italy and India, the genus Protocbaron from two oceanic islands Réunion and Amsterdam, very distant from one another, the genus Microcharon occurs not only on the Eutopean continent but also on the Mediterranean islands Corsica and Leucas, the genus Microparasellus on the Balkan Peninsula and in North Africa. Such a pattern of distribution is indicative of the great antiquity of these genera.

The family Thambematidae in contrast to the Microparasellidae and Microjaniridae is restricted to the abyssal. Thambema amicorum Stebbing was found in the North Atlantic $\left(54^{\circ} 33^{\prime} \mathrm{N}, 10^{\circ} 56^{\prime} \mathrm{W}\right)$ at a depth of $2490 \mathrm{~m}$ and Microthambema tenuis $\mathrm{n}$. sp. in the northwestern Pacific $\left(31^{\circ} 11.0^{\prime} \mathrm{N}, 143^{\circ} 09.7^{\prime} \mathrm{E}\right)$ at $5680.5690 \mathrm{~m}$.

If on the basis of the similarities described above, and, above all, on the presence of a well-developed first abdominal somite, these three families can be considered being closely related and primitive, a fairly accurate notion is obtained of the range of distribution of this group of Isopoda. This archaic group inhabits at present on the one hand fresh and marine interstitial waters, and on the other great oceanic depths.

A similar distribution is observed in some other archaic crustaceans, in particular in the amphipods of the suborder Ingolfiellidea. Three species are known from interstitial fresh waters of Jugoslavia, one species from the caves of the Congo, one shallow-water marine species lives among corals in the Gulf of Siam, and, finally one abyssal species was found in Davis Strait in a depth of $3521 \mathrm{~m}$. Concerning this type of distribution of the Ingolfiellidea Karaman (1959a) writes as follows: "Diese sonderbare Verteilung der Ingolfielliden auf vier Kontinente, überall in nur je einer Art, lässt vermuten, dass es sich um sehr alte, archaische Formen handelt, von welchen jede, als Relikt vergangener Zeit, wohl ein grösseres Areal der Verbreitung besitzen wird" (63).

Recently Ingolfiella was found in shell gravel off Plymouth from a depth of $42-48 \mathrm{~m}$ (Spooner, 1959a) and in interstitial cavities in rocky bottom on the coast of Peru (Siewing, 1959). These findings emphasize the similarity between the distribution of the group of genera of small Asellota considered here and that of the Ingolfiellidea.

Discussing the causes of the proximity of abyssal and shallow-water faunas, Siewing (1959) admits that: "... flockige Detritus kann möglicherweise in ruhigem Wasser ein ökologisches Aequivalent zum Sandbiotope bilden. Solche Stillwasserzonen wetden in grösseren Tiefen häufiger sein als in Flachwassergebieten..." (102). 
It must, however, be kept in mind that this similarity cannot be explained merely by ecological factors. The explanation of Siewing does not apply for instance to the isopod genus Janirella (which is now assigned to a special family Janirellidae, cf. Menzies, 1956), whose distribution is alike to that of Ingolfiellidea and Thambematidae-Microparasellidae-Microjaniridae. The genus Janivella includes seven deep-sea species from the North Atlantic, seven still undescribed deep-sea species from the North Pacific and one fresh-water species probably subterranean from Victoria. Nevertheless, Janirella with their flattened short body cannot be referred to the "Mesopsammal" and their life-habits are probably different from those of the Ingolfiellidea and the group of isopod families considered in this paper. To explain such a pattern of distribution not only ecological, but historical factors, too, must be taken into account as has been emphasised by Karaman (loc. cit.) in respect to the Ingolfiellidea.

The connection between the deep-sea oceanic fauna on the one hand and the interstitial freshwater and shallow marine fauna on the other, is of great significance to the controversial question on the age of the abyssal marine fauna. Groups where such connections are known to exist can be considered relicts of ancient faunas, once far more widely distributed. This lends strong support to the conception of the presence of many archaic elements in the deep-sea fauna (Zenkevitch and Birstein, 1960) and contradicts the idea of its geologically recent formation (Menzies and Imbrie, 1958).

\section{ZUSAMMENFASSUNG}

Aus dem nord-westlichen Pazifik aus der Tiefe von $5680-5690 \mathrm{~m}$ wird die neue Art und Gattung Microthambena tenuis beschrieben. Diese Art steht Thambema anticorm Stebbing aus grossen Tiefen des Atlantik nahe. Die Äholichkeit zwischen den Thambematidae und zwei Asselfamilien mit interstitiellen marinen und limnischen Vertretern (Microparasellidae, Microjaniridae) legt die Vermutung nahe, dass eine Verwandtschaft zwischen einigen Konponenten der Tiefseefauna und der interstitiellen marinen und limnischen Fauna existiert, was auch durch die Verbreitung der Ingolfielliden (Amphipodz) bestätigt wird. Diese Verbreitung entspricht der Vorstellung vom Altertum und Archaismus eines gewissen Teiles der Tiefseefauna.

\section{REFERENCES}

BIRSteIN, J. A, 1952. Some data on the origin of phreatic fauna. Trans. Hydrobiol. Assoc. USSR, 4: 225-229 (Russian).

BocQuet, CH., and C. LEvv, 1955. Microjaera anisopoda, n. sp. Isopode psammique de la sousfamille nouvelle des Microjanirinae. Arch. Zool. Expér. Gen., Notes et Revue, 92 (3): 116-134.

Chappuis, P. A., 1958 (1959). Crustacés des eaux douces de l'île Amsterdam. Protocharon antarctica n. sp. (Récoltes P. Paulian 1955-1956). Mém. Inst. Sci. Madagascar, 12: 13-24.

Chappuis, P. A. and C. Delamare Deboutteville, 1954. Les Isopodes psammiques de la Méditerranée. Arch. Zool. Expér. Gén., 91: 103-138.

Chappuis, P. A, C. Delamare Deboutievilie and R. Paulian, 1956. Crustacés des eaux souterraines littorales d'une résurgence d'eau douce à la Réunion. Mém. Inst. Sci. Madagascar, (A) 11: $51-78$.

Gnanamuthu, C. P., 1954. Two new sand-dwelling Isopods from the Madras sea-shore. Ann. Mag. Nat. Hist, (12) 7: 257.274.

Karmant, St., 1959. Uber eine neue Microcharon Art (Crust., Isopoda) aus dem Karstgebiete der Herzegowina. Acta Zool. Acad. Sci. Hung, (3/4): 333-338.

$\ldots$, 1959a. Uber die Ingolfielliden Jugoslaviens. Biol. Glasn., 12: $63 \cdot 80$. 
Matsumoto, K, 1956. On the two new subterranean water Isopods Mackinia japonica gen. et sp. nov and Asellus hubrichti sp. nov. Bull. Japan. Soc. Scient. Fish., 21 (12): 1219-1225.

Menzies, R. J.. 1956. New abyssal tropical Isopods. with observations on their biolog/. Amer. Mus. Nov., 1798: 1.16.

MEnzies, R. J. and J. IMBRIE, 1958. On the antiquity of the deep sea bottom fauna. Oikos, 9 (2): $192-210$.

Menzies, R. J. and J. Petjt, 1956. A new genus and species cf marine asellote isopod, Caecianitropsis psammophila, from California. Proc. U. S. Nat. Mus. 106 (3376) : 441-446

Schulz, E., 1954. Angeliera phreaticola aus Ischia. Ein Beitrag zur Kenntnis und Vetbreitung der Microparaselliden. Kieler Meeresforsch.. 10 (2): 253-260.

SIEWING, R, 1958. Ingolfiella ruffoi nov. spec., eine neue Ingolfieltide aus dem Grundwasser der Peruanischen Küste. Kieler Meeresforsch., 14 (1): $97-102$.

Spooner, G. M.. 1959. The octurrence of Micrucharon in the Plymouth offshore bottom fauna, with description of a new species. Journ. Mar. Biol. Assoc. U. K. 38 (1): 57.63.

- 1959a. New members of the British marine botton fauna. Nature, 183 (4676): 1695-1696.

Steberng. T. R. R. 1913. On the Crustacea Isopoda of the Porcupine Expedition. Trans. Zool. Soc. London, 20 (4): 231-239.

Zenkevitch, L. A and J. A. Birstein, 1960. On the problem of the antiquity of the deep-sea fauna. Deep-Sta Research, $7: 10 \cdot 23$. 